\title{
Gold-catalyzed intermolecular hydroamination of allenes with sulfonamides
}

\author{
Chen Zhang ${ }^{* 1}$, Shao-Qiao Zhang ${ }^{1}$, Hua-Jun Cai ${ }^{2}$ and Dong-Mei Cui ${ }^{* 2}$
}

\section{Full Research Paper}

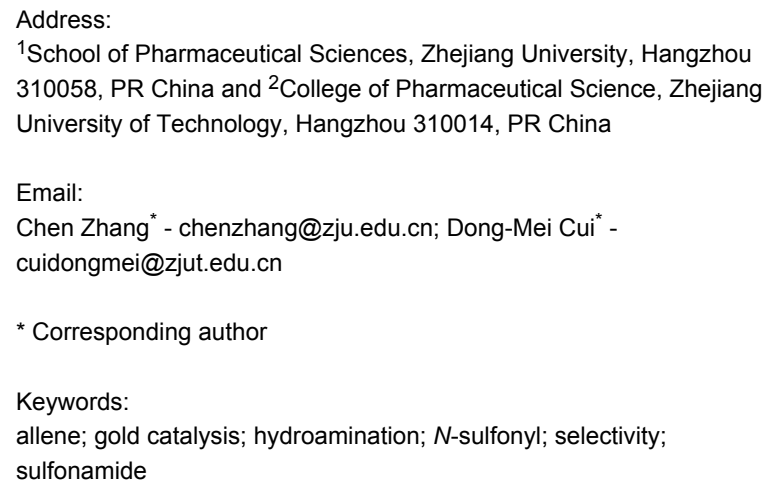

${ }^{1}$ School of Pharmaceutical Sciences, Zhejiang University, Hangzhou 310058, PR China and ${ }^{2}$ College of Pharmaceutical Science, Zhejiang University of Technology, Hangzhou 310014, PR China

Beilstein J. Org. Chem. 2013, 9, 1045-1050.

doi:10.3762/bjoc. 9.117

Received: 30 January 2013

Accepted: 07 May 2013

Published: 29 May 2013

This article is part of the Thematic Series "Gold catalysis for organic synthesis II".

Guest Editor: F. D. Toste

(c) 2013 Zhang et al; licensee Beilstein-Institut.

License and terms: see end of document.

\begin{abstract}
A co-catalyst of $\left(\mathrm{PPh}_{3}\right) \mathrm{AuCl} / \mathrm{AgOTf}$ for the intermolecular hydroamination of allenes with sulfonamides is shown. The reaction proceeded smoothly under mild conditions for differently substituted allenes giving $N$-allylic sulfonamides in good yields with high regioselectivity and $E$-selectivity.
\end{abstract}

\section{Introduction}

Hydroamination of an $\mathrm{N}-\mathrm{H}$ bond across a $\mathrm{C}-\mathrm{C}$ unsaturated bond represents one of the most effective and atom-economical methods to prepare amine derivatives [1-5]. In the case of using allenes, this reaction can lead to allylamines, which are invaluable precursors for the synthesis of natural products and other potentially biologically relevant substances [6]. In the literature, a wide range of catalytic intramolecular hydroaminations of allenes are known, but only a small number of intermolecular hydroamination reactions are reported [7-15]. More recently, $\mathrm{Au}(\mathrm{I}), \mathrm{Au}(\mathrm{III}), \mathrm{Pt}(\mathrm{II})$ and $\mathrm{Rh}(\mathrm{I})$ have been used for the intermolecular hydroamination of allenes with secondary alkylamines, ammonia, or carboxamide [7,16-24]. Although some of these advances have been efficiently made in hydroamination, many require extreme and extended reaction conditions. Thus, development of these reactions is still needed. Recently, Yamamoto and co-workers reported the $\operatorname{Pd}(0)$-catalyzed intermolecular hydroamination of allenes with sulfonamides [25]. In this paper, we wish to develop a gold(I)-complex-catalyzed addition of sulfonamides as the amine partner to allenes to synthesize $\mathrm{N}$-allylic sulfonamides with high regio- and stereoselectivity.

\section{Results and Discussion}

As part of our ongoing studies on metal-catalyzed reactions, we have reported the hydroalkoxylation of allenes with alcohols and hydroamination of alkynes with sulfonamides in the presence of gold catalysts [26-28]. On the basis of these studies, in 
an initial experiment, 1-phenyl-1,2-propadiene (1a) $(1.5 \mathrm{mmol})$ was treated with 4-methylbenzenesufonamide (2a) $(0.5 \mathrm{mmol})$ in the presence of $2 \mathrm{~mol} \%$ of $\left(\mathrm{PPh}_{3}\right) \mathrm{AuCl}$ and $8 \mathrm{~mol} \%$ of AgOTf in dioxane at $70{ }^{\circ} \mathrm{C}$ efficiently to form linear adduct 3a in $43 \%$ yield (Table 1 , entry 1 ). Different solvents were screened, and dioxane was found to be the most suitable one (Table 1, entries 2-4). Decreasing the amount of AgOTf resulted in lower yields (Table 1, entry 7). We were pleased to find that efficient hydroamination was realized at $\mathrm{rt}$ and led to a $91 \%$ yield of 3a with good regioselectivity and high $E$-selectivity (Table 1, entry 6). Other possible isomers could not be detected. As Ag catalysts, other salts were also screened, $\mathrm{AgBF}_{4}$ was ineffective. With $\mathrm{AgSbF}_{6}$ or $\mathrm{AgNTf}_{2}$, the reaction took place and gave adducts in $33 \%$ and $47 \%$ yield (Table 1 , entries 8 and 9). The use of the gold alone gave a lower yield, and the reaction did not proceed in the absence of gold or through the use of TfOH (entries 11-14). Finally, we determined the optimal conditions as $5 \mathrm{~mol} \%$ of $\left(\mathrm{PPh}_{3}\right) \mathrm{AuCl}$ and $8 \mathrm{~mol} \%$ of AgOTf in dioxane at rt (Table 1, entry 6).

To further assess the scope of this process, we first examined the hydroamination of $\mathbf{1 a}$ with several sulfonamides. Benzenesulfonamides containing $p-\mathrm{Br}$ or $p$ - $\mathrm{Cl}$ groups on the benzene ring were tolerated for the reaction, obtaining the corresponding adducts $\mathbf{3 d}$ and $\mathbf{3 e}$ in 54 and $72 \%$ yields, respectively (Table 2, entries 4-5). Under the same reaction conditions, the hydroamination of aliphatic sulfonamides took place smoothly to afford the corresponding $N$-allylic sulfonamide $3 \mathrm{f}$ with $56 \%$ yield (Table 2, entry 6). We also used $N$-substituted sulfonamide $\mathbf{2} \mathbf{g}$ as the amine partner. Although drastic conditions are required, the addition occurred to provide linear adduct $\mathbf{3 g}$ in good yield (Table 2, entry 7). In all cases, the adduct was obtained with high selectivity.

Various allenes were then examined, and aromatic rings of phenylallenes with either an electron-donating or an electronwithdrawing group gave good isolated yields of the corresponding adducts (Table 3 , entries 1 and 2). Whereas hydroamination of the monosubstituted heteroaromatic allene $\mathbf{1 d}$ also lead to the conversion into the expected addition product $\mathbf{3} \mathbf{j}$, hydroamination of the monoalkyl-substituted aliphatic allene $\mathbf{1 e}$ formed a 71:29 mixture of linear product (3ka) and branch product (3kb) under the same conditions (Table 3, entry 4). Furthermore, disubstituted allenes also worked well. Differentially 1,1-disubstituted allene $\mathbf{1 f}$ reacted with sulfonamide to afford trans-adducts $\mathbf{3 1}$ with high selectivity (Table 3, entry 5). Single crystals of the compound $\mathbf{3 l}$ suitable for X-ray crystallographic analysis were also obtained (Figure 1). This shows that $3 \mathbf{l}$ is the $E$ isomer, the sulfonamide carbon link being trans to the phenyl group (Figure 1). As for differentially 1,3- disubstituted allene $1 \mathrm{~g}$, hydroamination took place with exclusive attack of sulfonamide at the more electron-rich allene terminus to afford the corresponding adduct $\mathbf{3 m}$ with $68 \%$ yield and with high $E$-selectivity (Table 3, entry 6). In addition, hydroamination of trisubstituted allene $1 \mathrm{~h}$ took place to afford a different product (Table 3, entry 7). Single crystals of the compound $\mathbf{3 n}$

Table 1: Catalytic hydroamination of $1 \mathrm{a}$ and $2 \mathrm{a}^{\mathrm{a}}$

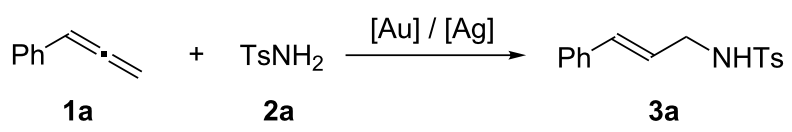

\begin{tabular}{|c|c|c|c|c|c|c|}
\hline Entry & {$[\mathrm{Au}](\mathrm{mol} \%)$} & {$[\mathrm{Ag}](\mathrm{mol} \%)$} & Solvent & Time $(\mathrm{h})$ & Temp. $\left({ }^{\circ} \mathrm{C}\right)$ & Yield $(\%)^{b}$ \\
\hline 1 & $\left(\mathrm{PPh}_{3}\right) \mathrm{AuCl}(2)$ & $\operatorname{AgOTf}(8)$ & dioxane & 4 & 70 & 43 \\
\hline 2 & $\left(\mathrm{PPh}_{3}\right) \mathrm{AuCl}(2)$ & $\operatorname{AgOTf}(8)$ & THF & 6 & 70 & 28 \\
\hline 3 & $\left(\mathrm{PPh}_{3}\right) \mathrm{AuCl}(2)$ & $\operatorname{AgOTf}(8)$ & toluene & 8 & 70 & 32 \\
\hline 4 & $\left(\mathrm{PPh}_{3}\right) \mathrm{AuCl}(2)$ & AgOTf (8) & $\left(\mathrm{CH}_{2} \mathrm{Cl}\right)_{2}$ & 7 & 70 & 33 \\
\hline 5 & $\left(\mathrm{PPh}_{3}\right) \mathrm{AuCl}(5)$ & $\operatorname{AgOTf}(8)$ & dioxane & 4 & 70 & 59 \\
\hline 6 & $\left(\mathrm{PPh}_{3}\right) \mathrm{AuCl}(5)$ & AgOTf (8) & dioxane & 16 & $\mathrm{rt}$ & 91 \\
\hline 7 & $\left(\mathrm{PPh}_{3}\right) \mathrm{AuCl}(5)$ & AgOTf (5) & dioxane & 16 & $\mathrm{rt}$ & 80 \\
\hline 8 & $\left(\mathrm{PPh}_{3}\right) \mathrm{AuCl}(5)$ & $\mathrm{AgSbF}_{6}(8)$ & dioxane & 24 & $\mathrm{rt}$ & 33 \\
\hline 9 & $\left(\mathrm{PPh}_{3}\right) \mathrm{AuCl}(5)$ & $\mathrm{AgNTf}_{2}(8)$ & dioxane & 24 & $\mathrm{rt}$ & 47 \\
\hline 10 & $\mathrm{Au}(\mathrm{NHC}) \mathrm{Cl}(5)$ & $\operatorname{AgOTf}(8)$ & dioxane & 16 & $\mathrm{rt}$ & 46 \\
\hline 11 & 0 & 0 & dioxane & 16 & $\mathrm{rt}$ & 0 \\
\hline 12 & $\left(\mathrm{PPh}_{3}\right) \mathrm{AuCl}(5)$ & 0 & dioxane & 16 & $\mathrm{rt}$ & 26 \\
\hline 13 & 0 & AgOTf (8) & dioxane & 16 & $\mathrm{rt}$ & 0 \\
\hline 14 & 0 & $\mathrm{TfOH}(8)$ & dioxane & 16 & $\mathrm{rt}$ & 0 \\
\hline
\end{tabular}

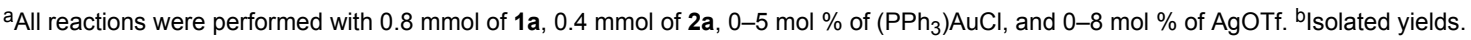




\begin{tabular}{|c|c|c|c|c|c|}
\hline Entry & Sulfonamide & 2 & Product & 3 & Yield $(\%)^{b}$ \\
\hline 1 & $\mathrm{TsNH}_{2}$ & $2 a$ & & $3 a$ & 91 \\
\hline 2 & $\mathrm{PhSO}_{2} \mathrm{NH}_{2}$ & $2 b$ & & $3 b$ & 76 \\
\hline 3 & o-Me- $\mathrm{C}_{6} \mathrm{H}_{4} \mathrm{SO}_{2} \mathrm{NH}_{2}$ & 2c & & $3 c$ & 60 \\
\hline 4 & $p-\mathrm{Br}-\mathrm{C}_{6} \mathrm{H}_{4} \mathrm{SO}_{2} \mathrm{NH}_{2}$ & 2d & & $3 d$ & 54 \\
\hline 5 & $p-\mathrm{Cl}-\mathrm{C}_{6} \mathrm{H}_{4} \mathrm{SO}_{2} \mathrm{NH}_{2}$ & $2 e$ & & $3 e$ & 72 \\
\hline 6 & $\mathrm{MeSO}_{2} \mathrm{NH}_{2}$ & $2 f$ & & $3 f$ & 56 \\
\hline $7^{c}$ & $n$-BuNHTs & $2 \mathrm{~g}$ & & $3 g$ & 79 \\
\hline
\end{tabular}

aThe reactions were performed with $0.8 \mathrm{mmol}$ of allene $1 \mathrm{a}, 0.4 \mathrm{mmol}$ of $2,5 \mathrm{~mol} \%$ of $\left(\mathrm{Ph}_{3} \mathrm{P}\right) \mathrm{AuCl}$ and $8 \mathrm{~mol} \%$ of $\mathrm{AgOTf}$ in $2 \mathrm{~mL}$ of dioxane at it for $16 \mathrm{~h}$. bisolated yield. ${ }^{\mathrm{C} A t} 100^{\circ} \mathrm{C}$ for $8 \mathrm{~h}$.

Table 3: Hydroamination of allenes $\mathbf{1}$ with 2a. ${ }^{a^{2}}$


Table 3: Hydroamination of allenes 1 with $2 a^{a}{ }^{\text {(continued) }}$

62

aThe reactions were performed with $0.8 \mathrm{mmol}$ of allene $1,0.4 \mathrm{mmol}$ of $2 \mathrm{a}, 5 \mathrm{~mol} \%$ of $\left(\mathrm{Ph}_{3} \mathrm{P}\right) \mathrm{AuCl}$ and $8 \mathrm{~mol} \%$ of $\mathrm{AgOTf}$ in $2 \mathrm{~mL}$ of dioxane at rt for 16 h. ${ }^{\text {b }}$ solated yield. ${ }^{\mathrm{c}} \mathbf{3 k a / 3 k b}=71: 29$.

suitable for X-ray crystallographic analysis were also obtained (Figure 2). This showed that $\mathbf{3 n}$ is the $E$ isomer, the sulfonamide being trans to the diphenylmethyl groups (Figure 2).

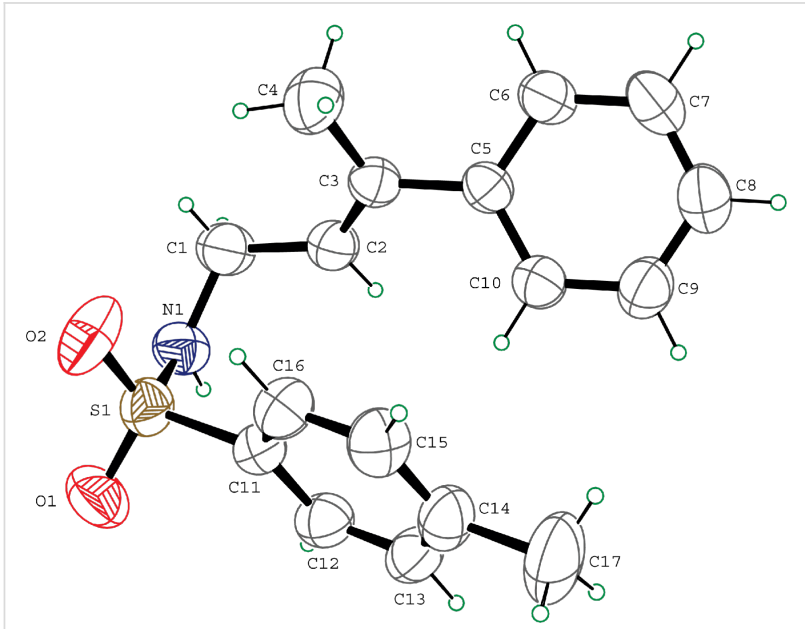

Figure 1: The X-ray structure of $3 \mathbf{3}$.

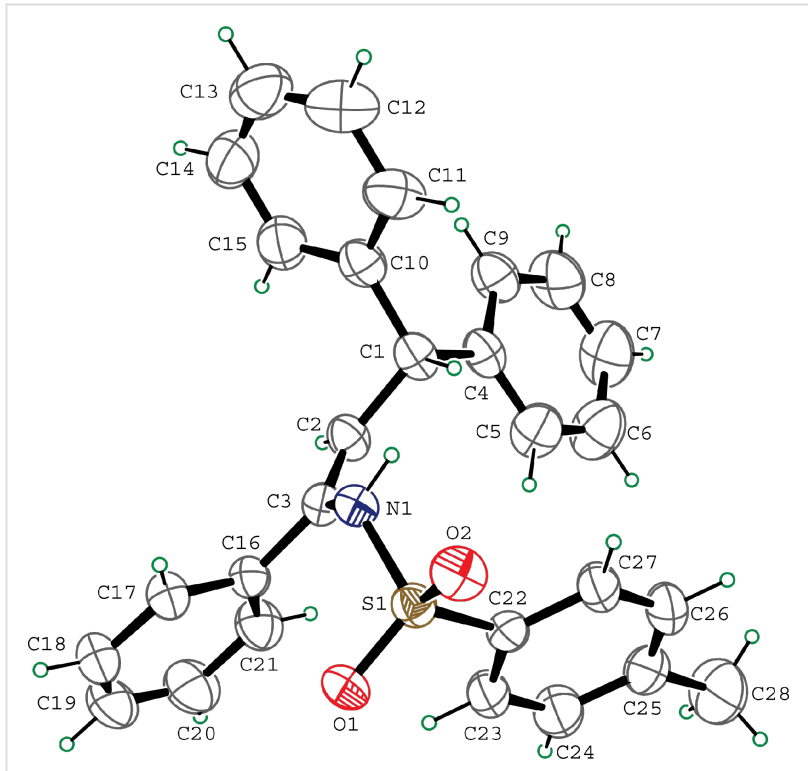

Figure 2: The X-ray structure of $3 n$.
The proposed mechanism of the gold-catalyzed hydroaamination of allenes is shown in Scheme 1 [2,7,29-36]. The gold cation coordinated with allene to form cationic $\mathrm{Au}(\mathrm{I})$-allene complex A, and this leads to cationic gold(I) complex B. The sulfonamide attacks at the less-substituted terminus of intermediate $\mathbf{B}$ to form $\mathbf{C}$. Protonolysis of the $\mathrm{Au}-\mathrm{C}$ bond of $\mathbf{B}$ yields the allylic sulfonamide $\mathbf{3}$, regenerating the gold complex. On the other hand, in comparison with phenyl-substituted allenes, for alkyl-substituted allene 1e, a mixture of $\mathbf{3} \mathbf{k a}$ and $\mathbf{3 k b}$ was produced; although the details are unclear, perhaps due to electronic factors, the addition of sulfonamide also occurred at the more-hindered position of intermediate $\mathbf{B}$ to give $\mathbf{3} \mathbf{k a}$ and $3 \mathbf{k b}$.

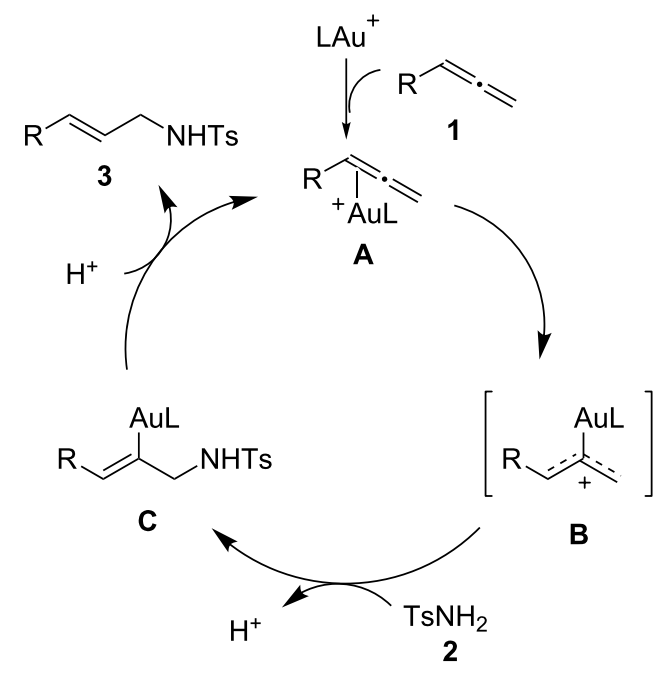

Scheme 1: Proposed mechanism for the hydroamination of allenes.

\section{Conclusion}

In conclusion, we have successfully employed $\left(\mathrm{PPh}_{3}\right) \mathrm{AuCl} /$ AgOTf catalyzed intermolecular hydroamination of allenes with sulfonamides to produce $\mathrm{N}$-allylic sulfonamide. This reaction takes place under mild conditions with effective and high regioand stereoselectivity. Monosubstituted, 1,1- and 1,3-disubstituted, and trisubstituted allenes were well tolerated in the reaction. 


\section{Experimental}

General Information: Unless otherwise noted, materials were obtained from commercial suppliers and used without further purification. Allenes were prepared by procedures in the literature [37-39]. Thin-layer chromatography (TLC) was performed on glass plates coated with silica gel 60 F254 and visualized by UV light (254 nm). Column chromatography was performed with silica gel (mesh 300-400). Infrared (IR) spectra were obtained on a 370 FTIR spectrometer; absorptions are reported in $\mathrm{cm}^{-1}$. Mass spectra were obtained in the electron impact (EI) mode, and high-resolution mass spectra were measured on a high-resolution mass spectrometer (GCT Premier).

General Procedure: To a mixture of sulfonamide $(0.4 \mathrm{mmol})$, $\mathrm{PPh}_{3} \mathrm{AuCl}(0.02 \mathrm{mmol})$, and AgOTf $(0.032 \mathrm{mmol})$ in anhydrous 1 ,4-dioxane $(2 \mathrm{~mL})$ was added allene $(0.8 \mathrm{mmol})$. The mixture was then sealed and stirred at room temperature until the starting sulfonamide was consumed as judged by TLC. The mixture was quenched with a saturated solution of $\mathrm{NaHCO}_{3}$ and then extracted with ethyl acetate $(3 \times 20 \mathrm{~mL})$. The organic layer was washed with brine, dried over $\mathrm{Na}_{2} \mathrm{SO}_{4}$ and concentrated in vacuo. The residue was purified by column chromatography (silica gel) to yield the product in an analytically pure form.

\section{Supporting Information}

\section{Supporting Information File 1}

Analytical and spectroscopic data for compounds $\mathbf{3 a}-\mathbf{3 j}$,

3ka, $3 \mathbf{k b}$ and $\mathbf{3 l - 3 n}$.

[http://www.beilstein-journals.org/bjoc/content/ supplementary/1860-5397-9-117-S1.pdf]

\section{Acknowledgements}

We thank the Hangzhou Natural Science Foundation (No. Y4100558) for financial support.

\section{References}

1. Müller, T. E.; Hultzsch, K. C.; Yus, F.; Foubelo, M.; Tada, M. Chem. Rev. 2008, 108, 3795. doi:10.1021/cr0306788

2. Widenhoefer, R. A.; Han, X. Eur. J. Org. Chem. 2006, 4555 doi:10.1002/ejoc.200600399

3. Pohlki, F.; Doye, S. Chem. Soc. Rev. 2003, 32, 104. doi:10.1039/b200386b

4. Hong, S.; Marks, T. J. Acc. Chem. Res. 2004, 37, 673. doi:10.1021/ar040051r

5. Hultzsch, K. C. Adv. Synth. Catal. 2005, 347, 367. doi:10.1002/adsc.200404261

6. Johannsen, M.; Jørgensen, K. A. Chem. Rev. 1998, 98, 1689. doi:10.1021/cr970343o

7. Kinder, R. E.; Zhang, Z.; Widenhoefer, R. A. Org. Lett. 2008, 10, 3157. doi:10.1021/ol8010858
8. Nishima, N.; Yamamoto, Y. Tetrahedron Lett. 2008, 49, 4908. doi:10.1016/j.tetlet.2008.05.152

9. Hannedouche, J.; Aillaud, I.; Collin, J.; Schulz, E.; Trifonov, A Chem. Commun. 2008, 3552. doi:10.1039/b804745f

10. Zi, G.; Xiang, L.; Song, H. Organometallics 2008, 27, 1242. doi:10.1021/om701058k

11. Zhang, Z.; Bender, C. F.; Widenhoefer, R. A. J. Am. Chem. Soc. 2007, 129, 14148. doi:10.1021/ja0760731

12. LaLonde, R. L.; Sherry, B. D.; Kang, E. J.; Toste, F. D. J. Am. Chem. Soc. 2007, 129, 2452. doi:10.1021/ja068819।

13. Zhang, Z.; Bender, C. F.; Widenhoefer, R. A. Org. Lett. 2007, 9, 2887. doi:10.1021/ol071108n

14. Volz, F.; Krause, N. Org. Biomol. Chem. 2007, 5, 1519. doi:10.1039/b703995f

15. Morita, N.; Krause, N. Eur. J. Org. Chem. 2006, 4634. doi:10.1002/ejoc.200600438

16. Nishina, N.; Yamamoto, Y. Angew. Chem., Int. Ed. 2006, 45, 3314 doi:10.1002/anie.200600331

17. Nishina, N.; Yamamoto, Y. Synlett 2007, 1767. doi:10.1055/s-2007-984501

18. Lavallo, V.; Frey, G. D.; Donnadieu, B.; Soleilhavoup, M.; Bertrand, G. Angew. Chem., Int. Ed. 2008, 47, 5224. doi:10.1002/anie.200801136

19. Zeng, X.; Soleilhavoup, M.; Bertrand, G. Org. Lett. 2009, 11, 3166. doi:10.1021/ol901418c

20. Toups, K. L.; Widenhoefer, R. A. Chem. Commun. 2010, 46, 1712. doi:10.1039/b925859k

21. Cooke, M. L.; Xu, K.; Breit, B. Angew. Chem., Int. Ed. 2012, 51, 10876. doi:10.1002/anie.201206594

22. Kim, H.; Lim, W.; Im, D.; Kim, D.-G.; Rhee, Y. H. Angew. Chem., Int. Ed. 2012, 51, 12055. doi:10.1002/anie.201206967

23. Butler, K. L.; Tragni, M.; Widenhoefer, R. A. Angew. Chem., Int. Ed. 2012, 51, 5175. doi:10.1002/anie.201201584

24. Kim, H.; Rhee, Y. H. J. Am. Chem. Soc. 2012, 134, 4011. doi:10.1021/ja2116298

25. Al-Masum, M.; Meguro, M.; Yamamoto, Y. Tetrahedron Lett. 1997, 38, 6071. doi:10.1016/S0040-4039(97)01370-1

26. Cui, D.-M.; Zheng, Z.-L.; Zhang, C. J. Org. Chem. 2009, 74, 1426. doi:10.1021/j0802513a

27. Cui, D.-M.; Yu, K.-R.; Zhang, C. Synlett 2009, 1103. doi:10.1055/s-0028-1088158

28. Cui, D.-M.; Zheng, J.-Z.; Yang, L.-Y.; Zhang, C. Synlett 2010, 809. doi:10.1055/s-0029-1219384

29. Zhang, Z.; Liu, C.; Kinder, R. E.; Han, X.; Qian, H.; Widenhoefer, R. A. J. Am. Chem. Soc. 2006, 128, 9066. doi:10.1021/ja062045r

30. Zhang, Z.; Widenhoefer, R. A. Org. Lett. 2008, 10, 2079. doi:10.1021/ol800646h

31. Kennedy-Smith, J. J.; Staben, S. T.; Toste, F. D. J. Am. Chem. Soc. 2004, 126, 4526. doi:10.1021/ja049487s

32. Zhang, J.; Yang, C.-G.; He, C. J. Am. Chem. Soc. 2006, 128, 1798. doi:10.1021/ja053864z

33. Hashmi, A. S. K.; Weyrauch, J. P.; Frey, W.; Bats, J. W. Org. Lett. 2004, 6, 4391. doi:10.1021/ol0480067

34. Liu, Y.; Song, F.; Song, Z.; Liu, M.; Yan, B. Org. Lett. 2005, 7, 5409. doi:10.1021/ol052160r

35. Kovács, G.; Ujaque, G.; Lledós, A. J. Am. Chem. Soc. 2008, 130, 853. doi:10.1021/ja073578i

36. Wang, Z. J.; Benitez, D.; Tkatchouk, E.; Goddard, W. A., III; Toste, F. D. J. Am. Chem. Soc. 2010, 132, 13064. doi:10.1021/ja105530q 
37. Searles, S.; Li, Y.; Nassim, B.; Robert Lopes, M.-T.; Tran, P. T.; Crabbé, P. J. Chem. Soc., Perkin Trans. 1 1984, 747. doi:10.1039/p19840000747

38. Baird, M. S.; Nizovtsev, A. V.; Bolesov, I. G. Tetrahedron 2002, 58, 1581. doi:10.1016/S0040-4020(02)00018-2

39. Régas, D.; Ruiz, J. M.; Afonso, M. M.; Palenzuela, J. A. J. Org. Chem. 2006, 71, 9153. doi:10.1021/jo061582r

\section{License and Terms}

This is an Open Access article under the terms of the Creative Commons Attribution License

(http://creativecommons.org/licenses/by/2.0), which permits unrestricted use, distribution, and reproduction in any medium, provided the original work is properly cited.

The license is subject to the Beilstein Journal of Organic Chemistry terms and conditions:

(http://www.beilstein-journals.org/bjoc)

The definitive version of this article is the electronic one which can be found at: doi:10.3762/bjoc. 9.117 